\title{
Pathogenicity of Metarhizium anisopliae isolates on Nezara viridula and Dichelops melacanthus in wheat crop
}

\section{Patogenicidade de isolados de Metarhizium anisopliae (Metsch.) sobre Nezara viridula e Dichelops melacanthus (Hemiptera: Pentatomidae) na cultura do trigo}

\author{
Martin Groth', Raul Filho', Vanessa Soares', Daniel Bernardi 1*

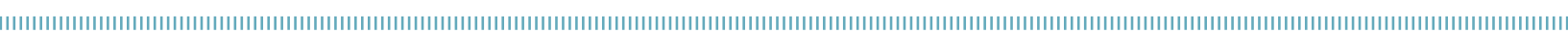

\begin{abstract}
Bugs such as Nezara viridula (Linnaeus) and Dichelops melacanthus (Dallas) are considered the main insect pests of wheat crop in Brazil. The use of the entomopathogenic fungus Metarhizium anisopliae (Metschnikoff) may be an alternative for the management of these insects in the crop. The objective of this work was to verify the pathogenicity of different isolates of $M$. anisopliae on adults of $N$. viridula and $D$. melacanthus under laboratory and greenhouse conditions. In the laboratory, isolates 05RA, 11RA, 08RA and 02RA were obtained from $N$. viridula and $D$. melacanthus infested with $M$. anisopliae. Also, a high pathogenicity (100\% of mortality) of both species was recorded in a bioassay of the topical application 8 Days After Application (DAA). However, compared to the other isolates, the 08RA isolate showed the highest pathogenicity in a shorter time interval for $N$. viridula (Mean Time "MT" $=2.8$ days) and D. melacanthus $(\mathrm{MT}=4.0$ days $)$. Under greenhouse conditions, the 08RA isolate provided a mortality of $44.9 \%$ ( $N$. viridula) and $35.7 \%$ (D. melacanthus) in the same evaluation period. However, at 14 DAA, the mortality was $100 \%$ for both species, with the MT values of $N$. viridula and $D$. melacanthus being obtained at 8 days and 10 days, respectively. The fungus $M$. anisopliae is a promising alternative for the control of adult $N$. viridula and D. melacanthus in wheat crop.
\end{abstract}

KEYWORDS: biological control; mortality; bugs; entomopathogenic fungi.
RESUMO: Os percevejos Nezaraviridula (Linnaeus) e o Dichelops melacanthus (Dallas) são considerados os principais insetos-pragas na cultura do trigo no Brasil. A utilizaçáo do fungo entomopatogênico Metarhiziumanisopliae (Metschnikoff) pode ser uma alternativa para o manejo destes insetos na cultura. O objetivo do trabalho foi verificar a patogenicidade de diferentes isolados de M.anisopliae sobre adultos de $N$. viridula ou $D$. melacanthus em condiçôes de laboratório e casa de vegetação. Em laboratório, os isolados 05RA, 11RA, 08RA e 02RA provenientes de adultos de $N$. viridula ou $D$. melacanthus, infestados a campo pelo fungo $M$. anisopliae, apresentaram elevada patogenicidade (100\% de mortalidade) de ambas as espécies em bioensaio de aplicação tópica 8 dias após aplicação (DAA). Entretanto, o isolado 08RA apresentou a maior patogenicidade em um menor intervalo de tempo para $N$. viridula (Tempo Médio "TM" = 2,8 dias) e D. melacanthus $(\mathrm{TM}=4,0$ dias $)$ em relação aos demais isolados. Em casa de vegetação, o isolado 08RA proporcionou mortalidade de 44,9\% (N. viridula) e 35,7\% (D. melacanthus) no mesmo período de avaliação. Contudo, aos 14 DAA, a mortalidade foi de $100 \%$ para ambas as espécies, com valores de TM de 8 dias e 10 dias para $N$. viridula e $D$. melacanthus, respectivamente. $\mathrm{O}$ fungo $M$. anisopliae constitui uma alternativa promissora de controle de adultos de $N$. viridula ou $D$. melacanthus na cultura do trigo.

PALAVRAS-CHAVE: controle biológico; mortalidade; percevejos; fungos entomopatogênicos. 


\section{INTRODUCTION}

In Brazil, mainly the Central-West and South regions, changes in the agricultural production of soybean and corn in summer and wheat in winter, are associated with the expansion of the direct sowing system. This has triggered the population growth of some species of bugs, such as Nezara viridula stink bug (Linnaeus, 1758) and the belly-green stink bug Dichelops melacanthus (Dallas, 1851) (Hemiptera: Pentatomidae) in wheat crop (CHOCOROSQUI; PANIZZI, 2004; PANIZZI, 2014). Damage is characterized during all stages of crop development, with the highest losses observed during grain formation (CHOCOROSQUI; PANIZZI, 2004). The damage caused by $D$. melacanthus is more serious during the growth phase of the crop (vegetative phase), because of the injection of saliva at the time of feeding. This causes transverse punctures, necrosis, winding and/or drying of the aerial part (GOMEZ; ÁVILA, 2004; MANFREDI-COIMBRA et al., 2005). However, the occurrence of $N$. viridula is greater during the reproductive phase (development of the spikes), which may lead to drying of the spikes and death of the plants (MANFREDI-COIMBRA et al., 2005).

The use of insecticide seed dressing with neonicotinoid insecticides for the control of D. melacanthus, or aerial sprays with pyrethroids and phosphorus during the flowering period, are the most used control methods for the management of these species in wheat (WAQUIL; OLIVEIRA, 2009). Due to the possibility of emergence of insect-resistant bug populations in Brazil (SOSA-GÓMEZ; SILVA, 2010), and the presence of chemical residues in the grains and food contamination (TIBOLA et al., 2009), studies are needed to establish the availability of new alternatives for the handling of these insect pests. In this context, biological control with the use of entomopathogenic fungi M. anisopliae (Metschnikoff) (Deuteromycetes) may be a viable alternative for the management of $N$. viridula and $D$. melacanthus in wheat. Several studies have shown that the fungus presented high pathogenicity to different species of bugs (SOSA-GÓMEZ; MOSCARDI, 1998; MARTINS et al., 2004; XAVIER; ÁVILA, 2006; RAMPELOTTI et al., 2007), especially to the sugarcane leafhopper, Mahanarva posticata (Stal, 1855) (Hemiptera: Cercopidae) (LOUREIRO et al., 2012).

Due to the evidence of the high pathogenicity of $M$. anisopliae in insects and the capacity of multiplication in the laboratory (ROHDE et al., 2006), the selection of isolates of this fungus for the control of $N$. viridula or $D$. melacanthus may provide subsidies for the management of these wheat crop pests. The objective of the present work was to evaluate the pathogenicity of $M$. anisopliae isolates on $N$. viridula and D. melacanthus adults in laboratory and greenhouse conditions.

\section{MATERIALS AND METHODS}

The bioassays were conducted at the Microbiology Laboratory of the University of Western Santa Catarina, São Miguel do Oeste, SC. All experiments were conducted under controlled environmental conditions (Temperature $27 \pm 1^{\circ} \mathrm{C}$, Relative Humidity $70 \pm 10 \%$ and photoperiod $12 \mathrm{~h}$ ).

\section{Breeding and maintenance of bugs in the laboratory}

The breeding of $N$. viridula and $D$. melacanthus was established through laboratory maintenance and by placing the insects on an artificial diet for two years. The insects were kept in plastic containers $(15 \times 20 \times 10 \mathrm{~cm})$, lined with dry filter paper and fed with bean pods (Phaseolus vulgaris L.), soybeans (Glycine $m a x$ ), and raw peanuts (Arachis hypogaea L.) according to the methodology proposed by SILVA et al. (2008). For aeration, the lids of the plastic container were cut to size in $1 \mathrm{~cm}^{2}$ diameter, using an organically coated fabric. The cages and food were changed twice a week to avoid contamination. The breeding and maintenance of the insects were carried out in an air-conditioned room as previously described. After the emergence of the egg masses, the eggs were removed and packed in Petri dishes $(9 \mathrm{~cm}$ in diameter) lined with moistened filter paper. After the hatching of the nymphs, they were individualized in plastic pots (20 nymphs per pot $-250 \mathrm{~mL}$ ), lined with dry filter paper, fed with bean pods, soybeans and raw peanuts until the adults were obtained. Throughout the breeding process (nymphs and adults) the water was supplied by moistened cotton, and placed internally in an Eppendorf tube $(10 \mathrm{~mL})$.

\section{Obtaining and multiplying the isolates of $M$. anisopliae}

The isolates of the entomopathogenic fungus $M$. anisopliae (isolates 05RA, 11RA, 08RA and 02RA) used in the bioassays were collected and selected from $N$. viridula and D. melacanthus bugs killed and contaminated by the fungus in wheat fields of the experimental areas of the University of Western Santa Catarina (Latitude 26 $43^{\prime} 33^{\prime \prime}$ S and Longitude 5331'5"W). In the laboratory, adults of contaminated bugs were transferred to a PDA (Potato + dextrose + agar + chloramphenicol - $0.5 \mathrm{~g}$ per $1 \mathrm{~L}$ water) culture medium (PITT; HOCKING, 1997), distributed in Petri dishes $(8.5 \mathrm{~cm}$ diameter $\times 1.0 \mathrm{~cm}$ in height) containing antibiotics to inhibit any bacterial contamination (ALVES et al., 1998). The isolates were incubated for 5 to 10 days in a BOD chamber (Temp. $27 \pm 1^{\circ} \mathrm{C}$; $60 \pm 10 \% \mathrm{RU}$ and 12-h photo.) for fungal growth and sporulation. After this period, the isolates were collected in Petri dishes containing a PDA culture medium to obtain pure isolates and to eliminate any type of impurities (eg. contamination by bacteria). The total purity was obtained by cultivating 
the isolates in colonies which originated from a single conidium (spore), following the methodology proposed by ALVES et al. (1998). Subsequently, M. anisopliae isolates were replicated in Petri dishes containing a PDA culture medium, as described previously, following the methodology proposed by PITT; HOCKING (1997). After 15 days of growth and sporulation, the fungus was scraped from the culture medium with the aid of a spatula sterilized in a Neubauer chamber and placed in sterile distilled water. The concentration was adjusted to $10^{8}$ conidia. $\mathrm{mL}^{-1}$ for use in the bioassays of the topical application.

\section{Pathogenicity of M. anisopliae isolates on $\mathbf{N}$. viridula and D. melacanthus in the laboratory}

The efficiency and pathogenicity of $M$. anisopliae (isolates $05 \mathrm{RA}$, 11RA, 08 RA and 02RA) on N. viridula and D. melacanthus adults were evaluated by the topical application bioassay at a concentration of $10^{8}$ conidia. $\mathrm{mL}^{-1}$. The concentration provided the highest mortality of adults of both species of bugs in the preliminary bioassays. The experimental units consisted of Gerbox ${ }^{\mathrm{TM}}$ type plastic boxes $(11.0 \times 11.0 \times 3.5 \mathrm{~cm})$ having lids disinfected with sodium hypochlorite $(1 \%)$ and lined at the bottom with filter paper. They were also left exposed in a chamber with ultraviolet light $(365 \mathrm{~nm})$ for $15 \mathrm{~min}$. Subsequently, in each experimental unit six adults of $N$. viridula or D. melacanthus (four days of age) and one bean pod were placed as feed substrate. The food was changed every two days, the moisture was restored with distilled water and sterilized using an already sterilized pipette $(10 \mathrm{~mL})$. Prior to the release of bugs into the Gerbox ${ }^{\text {TM }}$ boxes, the adults were placed in contact with sodium hypochlorite solution (1\%) for $5 \mathrm{~s}$, and then in distilled water to eliminate any contamination. Then, $24 \mathrm{~h}$ after the insects were released in the boxes, the topical application was introduced by applying $1 \mathrm{~mL}$ of the homogenized solution (concentration of $10^{8}$ conidia. $\mathrm{mL}^{-1}$ ) to each isolate (treatments 05RA, 11RA, 08RA and 02RA) in the pronot region of the insects. This was achieved with the aid of a micropipette of $1,000 \mu \mathrm{l}$, corresponding to approximately 500,000 conidia/insect estimated in Neubauer's chamber (ALVES et al., 1998). After the application, the insects were packed in a heated BOD chamber. The experimental design was completely randomized with four treatments (isolates) and a control treatment (water). Each treatment consisted of 20 replicates $\left(\operatorname{Gerbox}^{\mathrm{TM}}\right)$ with six adults of $N$. viridula or $D$. melacanthus per replicate. The parameters evaluated were mortality at 0, 2, 4, 6 and 8 days after application (DAA), and mean mortality during the eight-day period. The mortality was corrected by HENDERSON; TILTON formula (1955). For each treatment, confirmation of the mortality of bugs was performed by isolating and packing three dead insects by repetition inside sterile Petri dishes containing a PDA medium (as described above), sealed at the top with parafilm ${ }^{\mathrm{TM}}$ and placed in BOD for five days. Time was required to verify the growth of spores of $M$. anisopliae on insects, by using a stereoscopic microscope (40x), and the adult mortality of the entomopathogenic fungus was characterized after application.

\section{Pathogenicity of $M$. anisopliae on $N$. viridula and $D$. melacanthus in a greenhouse}

For this purpose, wheat was sown using the cv. "TBIO Alvorada" in a plastic vessel (8L), 10 seeds per pot containing soil and vegetable substrate in a ratio of $1: 1$. Seven days after sowing, the plants were thinned, leaving five plants per pot and later, all the cultural treatments were adopted according to the recommendation for the cultivation of wheat in the State of Santa Catarina (EMBRAPA, 2011). At the phenological stage of frutification, the plants were infested with six adults of $N$. viridula or $D$. melacanthus per pot. In order to carry out the infestation, 4-day-old insects were obtained with the aid of a flat bottom glass tube $(2.5 \mathrm{~cm}$ in diameter $\times 8.5 \mathrm{~cm}$ in height), and placed at the base of the wheat plants. After 2 days of infestation, the fungus $M$. anisopliae (08RA isolate) from the laboratory stock solution was sprayed with a hand sprayer (PCP 424, Guarany $\left.{ }^{\mathrm{TM}}, 1 \mathrm{~L}\right)$ at a pressure of $10 \mathrm{lb} / \mathrm{in}^{2}$, in a volume of $20.0 \mathrm{~mL}$ of aqueous suspension at a concentration of $10^{8}$ conidia. $\mathrm{mL}^{-1}$. After infestation and spraying, to avoid insect escape, the plants were housed inside cages made of voile fabric $(70 \mathrm{~cm}$ high $\times 40 \mathrm{~cm}$ in diameter $)$ suspended by galvanized wire frames. As a control treatment, the wheat plants used were infested with adults of $N$. viridula or D. melacanthus, but sprayed with water. The parameters evaluated were mortality at $0,2,4,6,8,10,12$ and 14 DAA and the mean mortality time was determined. The experimental design was completely randomized with 20 replicate "pots" having five wheat plants per replicate and containing six adults of $N$. viridula or D. melacanthus per pot. The mortality was corrected by HENDERSON; TILTON formula (1955). To confirm the adult mortality of $N$. viridula and D. melacanthus by $M$. anisopliae (08RA isolate), three insects per replicate were collected and placed in sterile Petri dishes containing PDA medium as previously described. The insects were characterized as dead when the fungus presented the development or growth of spores (conidia) on the body.

\section{Statistical Analysis}

All data were analyzed using the Bartlett Shapiro-Wilk (PROC UNIVARIATE) (SAS INSTITUTE, 2011) normality test. Subsequently, the data were transformed by $\sqrt{ } \mathrm{x}+0.1$ and 
submitted for analysis of variance (ANOVA) and the means compared by the Tukey test at a level of $0.05 \%$ significance (SAS INSTITUTE, 2011).

\section{RESULTS}

\section{Pathogenicity of M. anisopliae isolates from the laboratory}

The germination of conidia on the dead insects was observed in the laboratory, after being placed in the PDA medium. This confirmed that adults of $N$. viridula and D. melacanthus were highly susceptible to $M$. anisopliae in bioassays of topical application, since conidia were present in $100 \%$ of the insects sampled using a stereoscopic microscope (40x).

There was a significant interaction between time and exposure of $N$. viridula or $D$. melacanthus to $M$. anisopliae fungus, with mortality of $100 \%$ of adults at 8 DAA (Table 1). Through polynomial regression analysis, it was found that the isolate 08RA presented greater pathogenicity as a function of time, with a mortality peak at 2.82 days for $N$. viridula (Figure 1) and 3.93 days for D. Melacanthus (Figure 2).Compared to the control, statistical difference was recorded $(\mathrm{F}=7.584$; d.f. $=19,4 ; \mathrm{P}<0.0001)$ for the other isolates evaluated: 05RA and 11RA (3.0 days) and 02RA (4.95 days) for $N$. viridula (Figure1) and 05RA (3.59 days), 11RA (3.37 days) and 02RA (8.0 days) for D. melacanthus (Figure 2, Table 2). The 08RA isolate was selected for greenhouse bioassays due to the greater pathogenicity recorded within a short period of time.

\section{Efficiency of M. anisopliae under greenhouse conditions}

In greenhouse bioassays, there was a significant interaction between the isolate (08RA) and the exposure time of adults of $N$. viridula $(\mathrm{F}=0.866$, d.f. $=19,1 ; \mathrm{P}<0.001)$ and $D$. melacanthus $(\mathrm{F}=0.026$; d.f. $=19.1 ; \mathrm{P}<0.001)$ to $M$. anisopliae $($ Table 2$)$. Through polynomial regression analysis, it was verified that at $8 \mathrm{DAA}$, the highest mortality peak occurred as a function of the mean time (MT) for N. viridula (58\% mortality) and for D. melacanthus (50\% mortality) (Figure 3). However, at 14 DAA, mortality was $100 \%$ for both studied species (Table 2), statistically differing $(\mathrm{F}=0.125$, d.f. $=19,1 ; \mathrm{P}<0.001)$ from the control treatment with a mortality of $16.7 \%$ for both species (Table 2).

\section{DISCUSSION}

The high infectivity of $M$. anisopliae isolates on adults of $N$. viridula and $D$. melacanthus was evidenced by the presence of the hardened body and large amounts of $M$. anisopliae spores on the body of the insects in postmortem observations. Also, a direct relationship was observed between the time of application and the mortality of the bug species, with a maximum mortality near 3 and 5DAA. However, at 8 DAA, both isolates of $M$. anisopliae provided $100 \%$ of mortality in the laboratory

Table 1. Average number of live insects ( $\mathrm{N} \pm$ Standard Error (SE)) and cumulative mortality (\%M) of $N$. viridula or $D$. melacanthus adults exposed to different isolates of $M$. anisopliae in the laboratory.

\begin{tabular}{|c|c|c|c|c|c|c|c|c|}
\hline \multirow{3}{*}{ Isolates } & \multicolumn{8}{|c|}{ Days After Application (DAA) } \\
\hline & \multicolumn{2}{|l|}{2} & \multicolumn{2}{|l|}{4} & \multicolumn{2}{|l|}{6} & \multicolumn{2}{|l|}{8} \\
\hline & $\mathbf{N} \pm \mathbf{S E}^{1}$ & $\% \mathbf{M}^{2}$ & $\mathbf{N} \pm \mathbf{S E}^{1}$ & $\% M^{2}$ & $\mathbf{N} \pm \mathbf{S E}^{1}$ & $\% M^{2}$ & $\mathbf{N} \pm \mathbf{S E}^{1}$ & $\% \mathrm{M}^{2}$ \\
\hline \multicolumn{9}{|c|}{ Nezaraviridula } \\
\hline O8RA & $5.10 \pm 0.03 \mathrm{~A}$ & 15.0 & $0.75 \pm 0.03 \mathrm{~A}$ & 87.2 & $0.00 \pm 0.0 \mathrm{~A}$ & 100.0 & - & - \\
\hline 05RA & $5.50 \pm 0.04 \mathrm{~A}$ & 8.3 & $2.20 \pm 0.03 \mathrm{~B}$ & 62.7 & $0.45 \pm 0.03 \mathrm{~B}$ & 91.8 & $0.00 \pm 0.00 \mathrm{~A}$ & 100 \\
\hline $11 \mathrm{RA}$ & $4.70 \pm 0.03 \mathrm{~A}$ & 21.6 & $2.11 \pm 0.04 \mathrm{~B}$ & 64.4 & $0.50 \pm 0.03 \mathrm{~B}$ & 90.9 & $0.00 \pm 0.00 \mathrm{~A}$ & 100 \\
\hline O2RA & $5.10 \pm 0.04 \mathrm{~A}$ & 15.0 & $3.15 \pm 0.04 \mathrm{~B}$ & 46.6 & $1.15 \pm 0.04 \mathrm{C}$ & 79.1 & $0.00 \pm 0.00 \mathrm{~A}$ & 100 \\
\hline Control & $6.00 \pm 0.01 \mathrm{~B}$ & 0.0 & $5.90 \pm 0.01 \mathrm{C}$ & 1.6 & $5.50 \pm 0.01 \mathrm{D}$ & 8.3 & $5.1 \pm 0.02 \mathrm{~B}$ & 15 \\
\hline \multicolumn{9}{|c|}{ Dichelops melacanthus } \\
\hline O8RA & $4.85 \pm 0.04 \mathrm{~A}$ & 17.1 & $0.85 \pm 0.031 \mathrm{~A}$ & 84.8 & $0.00 \pm 0.0 \mathrm{~A}$ & 100.0 & - & - \\
\hline O5RA & $5.50 \pm 0.04 \mathrm{~A}$ & 5.9 & $3.15 \pm 0.028 B$ & 44.6 & $0.95 \pm 0.02 \mathrm{~B}$ & 82.2 & $0.00 \pm 0.0 \mathrm{~B}$ & 100.0 \\
\hline $11 \mathrm{RA}$ & $5.51 \pm 0.05 \mathrm{~A}$ & 5.9 & $3.15 \pm 0.034 \mathrm{~B}$ & 44.6 & $1.35 \pm 0.02 \mathrm{~B}$ & 74.8 & $0.00 \pm 0.0 \mathrm{~B}$ & 100.0 \\
\hline O2RA & $5.65 \pm 0.03 \mathrm{~A}$ & 3.4 & $4.00 \pm 0.045 B$ & 28.6 & $2.15 \pm 0.03 \mathrm{~B}$ & 59.8 & $0.00 \pm 0.0 \mathrm{~B}$ & 100.0 \\
\hline Control & $5.85 \pm 0.01 \mathrm{~A}$ & 0.7 & $5.65 \pm 0.011 \mathrm{C}$ & 6.7 & $5.35 \pm 0.02 \mathrm{C}$ & 10.8 & $4.80 \pm 0.02 C$ & 20.0 \\
\hline
\end{tabular}

${ }^{1}$ Means followed by uppercase letters in the column do not differ from each other by the Tukey test $(P \leq 0.05) ;{ }^{2}$ Mortality corrected by the HENDERSON; TILTON (1955). 
bioassay in both bug species, corroborating with other studies that verified the mortality of over $80 \%$ of adults of Scaptocoris carvalhoi Becker (Hemiptera: Cydnidae) (XAVIER; ÁVILA, 2006) and of Mahanarva fimbriolata (Stal, 1854) (Hemiptera: Cercopidae) in sugarcane culture (CARVALHO et al., 2011).
The highest infection rate and adult mortality of $N$. viridula and $D$. melacanthus in laboratory bioassays when compared to greenhouse bioassays may be related to the mode of inoculation of the pathogen. In the laboratory, the fungus $M$. anisopliae was applied directly to the pronotum of the
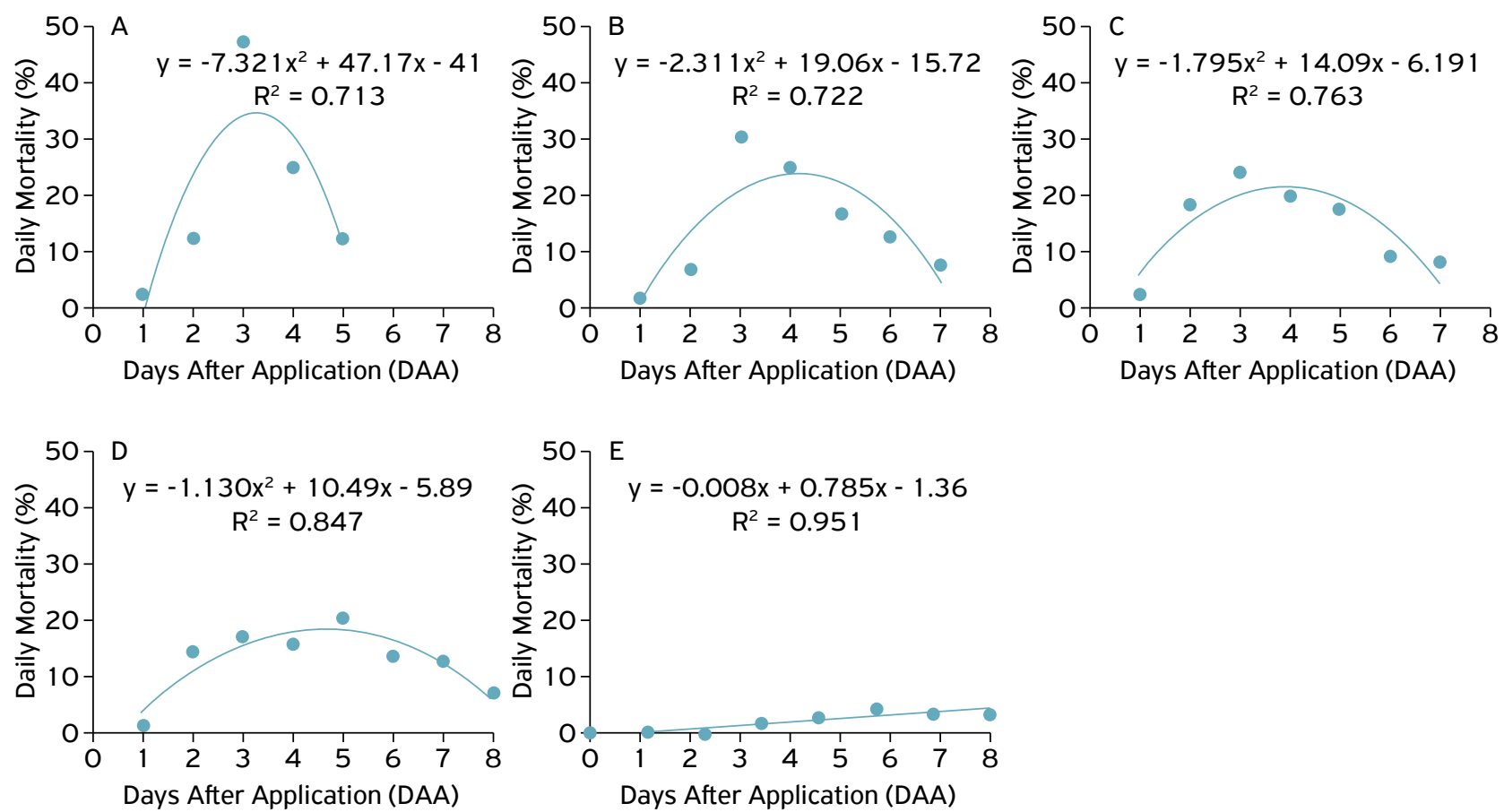

Figure 1. Daily mortality of $N$. viridula after application of different isolates of the M. anisopliae in the laboratory. (A) O8RA isolate; (B) 05RA isolate; (C)11RA isolate;(D) O2RA isolate;(E) Control.
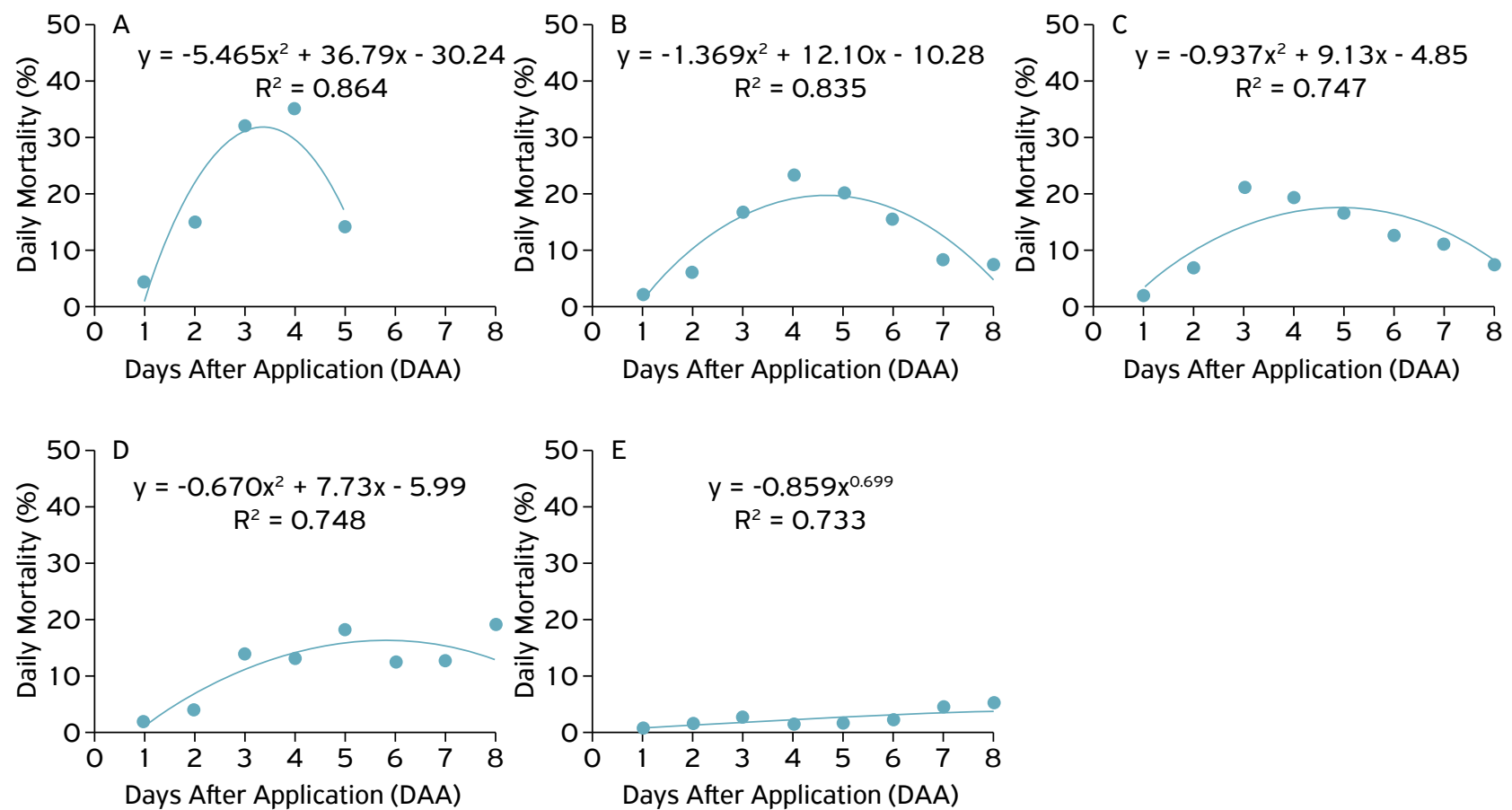

Figure 2. Daily mortality of $D$. melacanthus after application of different isolates of the $M$. anisopliae in the laboratory. (A) O8RA isolate; (B) 05RA isolate; (C) 11 RA isolate, (D) O2RA isolate; (E) Control. 
insects and later placed in closed plastic boxes $\left(\mathrm{Gerbox}^{\mathrm{TM}}\right)$ and stored under controlled conditions of temperature and humidity. This isolation condition provided a suitable microclimate for the development, multiplication and penetration of the spores in the body of the insects, unlike what happened in greenhouse bioassays, where the solution was sprayed on the insects. The technique of spraying the solution on the insects provides a lower deposition of $M$. anisopliae on the body of the individuals, which increased the time required for the penetration of the spores inside the individuals, and consequently, the establishment of the colony in the host (MENT et al., 2010;AW; HUE, 2017).

Table 2. Average number of live insects $(\mathrm{N} \pm \mathrm{SE}$ ) and accumulated mortality (\%M) of $N$. viridula or $D$. melacanthus adults exposed to M. anisopliae 08RA isolate under greenhouse conditions.

\begin{tabular}{|c|c|c|c|c|c|c|c|c|c|c|c|c|c|c|}
\hline \multirow{3}{*}{ Treatment } & \multicolumn{14}{|c|}{ Days After Application (DAA) } \\
\hline & \multicolumn{2}{|l|}{2} & \multicolumn{2}{|l|}{4} & \multicolumn{2}{|l|}{6} & \multicolumn{2}{|l|}{8} & \multicolumn{2}{|l|}{10} & \multicolumn{2}{|l|}{12} & \multicolumn{2}{|l|}{14} \\
\hline & $\mathbf{N} \pm \mathbf{S E}^{1}$ & $\% M^{2}$ & $\mathbf{N} \pm \mathbf{S E}^{1}$ & $\% \mathrm{M}^{2}$ & $\mathbf{N} \pm \mathbf{S E}^{1}$ & $\% \mathrm{M}^{2}$ & $\mathbf{N} \pm \mathbf{S E}^{1}$ & $\% \mathrm{M}^{2}$ & $\mathbf{N} \pm \mathbf{S E}^{1}$ & $\% \mathrm{M}^{2}$ & $\mathbf{N} \pm \mathbf{S E}^{1}$ & $\% \mathrm{M}^{2}$ & $\mathbf{N} \pm \mathbf{S E}^{1}$ & $\% \mathrm{M}^{2}$ \\
\hline \multicolumn{15}{|c|}{ Nezara viridula } \\
\hline O8RA & $5.80 \pm 0.03 \mathrm{~A}$ & 1.7 & $5.30 \pm 0.02 \mathrm{~A}$ & 8.6 & $4.35 \pm 0.03 \mathrm{~A}$ & 23.9 & $3.0 \pm 0.02 \mathrm{~A}$ & 44.9 & $1.7 \pm 0.04 \mathrm{~A}$ & 66.3 & $0.8 \pm 0.03 \mathrm{~A}$ & 84.0 & $0.0 \pm 0.00 \mathrm{~A}$ & 100.0 \\
\hline Control & $5.90 \pm 0.01 \mathrm{~A}$ & 1.7 & $5.80 \pm 0.01 \mathrm{~A}$ & 3.3 & $5.65 \pm 0.01 \mathrm{~B}$ & 5.8 & $5.2 \pm 0.01 \mathrm{~B}$ & 9.2 & $5.2 \pm 0.01 \mathrm{~B}$ & 9.2 & $5.0 \pm 0.01 \mathrm{~B}$ & 16.7 & $5.0 \pm 0.01 B$ & 16.7 \\
\hline \multicolumn{15}{|c|}{ Dichelops melacanthus } \\
\hline O8 RA & $5.80 \pm 0.03 \mathrm{~A}$ & 1.7 & $5.45 \pm 0.03 \mathrm{~A}$ & 5.2 & $4.60 \pm 0.04 \mathrm{~A}$ & 20.3 & $3.5 \pm 0.03 \mathrm{~A}$ & 35.7 & $2.4 \pm 0.04 \mathrm{~A}$ & 55.1 & $1.8 \pm 0.02 \mathrm{~A}$ & 84.0 & $0.0 \pm 0.00 \mathrm{~A}$ & 100.0 \\
\hline Control & $5.90 \pm 0.02 \mathrm{~A}$ & 1.6 & $5.75 \pm 0.02 \mathrm{~A}$ & 4.2 & $5.20 \pm 0.02 B$ & 13.3 & $5.2 \pm 0.01 \mathrm{~B}$ & 13.3 & $5.2 \pm 0.02 \mathrm{~B}$ & 13.3 & $5.0 \pm 0.01 \mathrm{~B}$ & 16.7 & $5.0 \pm 0.01 \mathrm{~B}$ & 16.7 \\
\hline
\end{tabular}

'Means followed by uppercase letters in the column do not differ from each other by the Tukey test $(P \leq 0.05) ;{ }^{2}$ Mortality corrected by the HENDERSON; TILTON formula (1955).
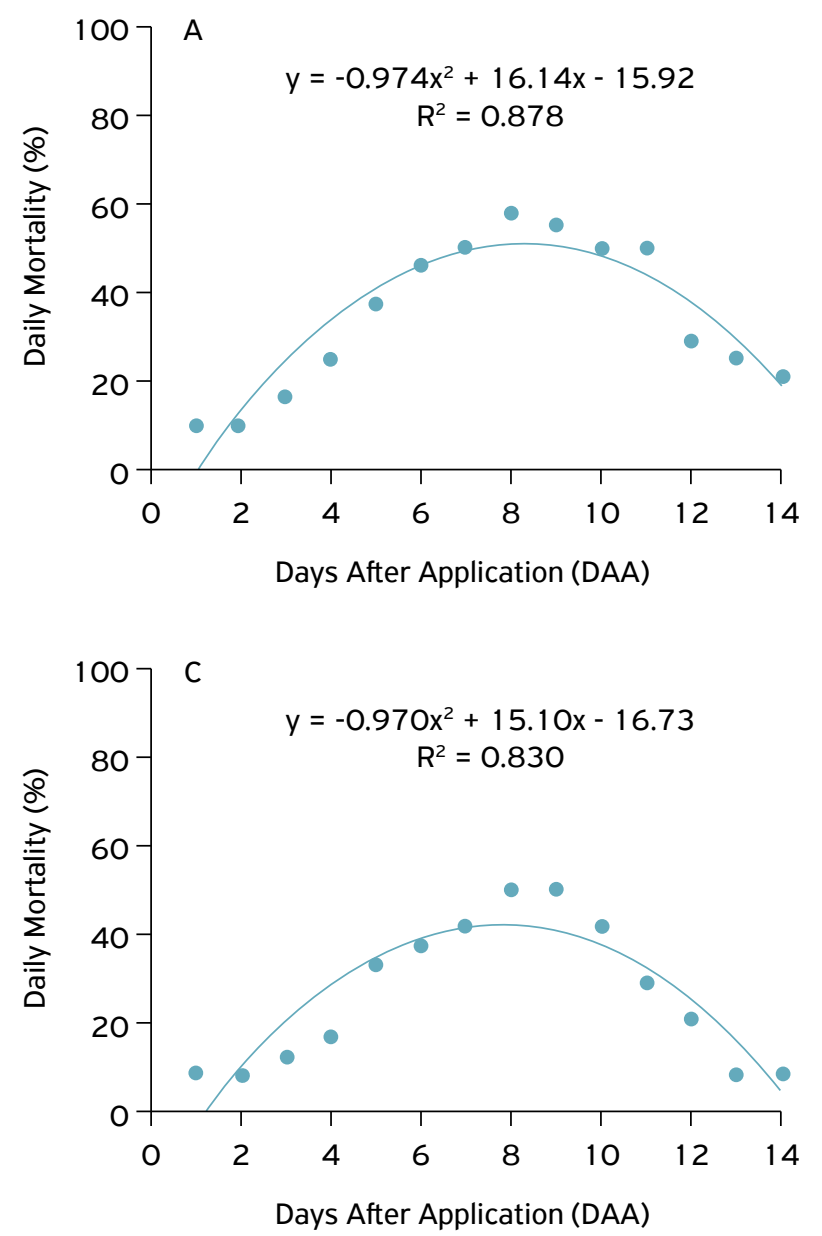
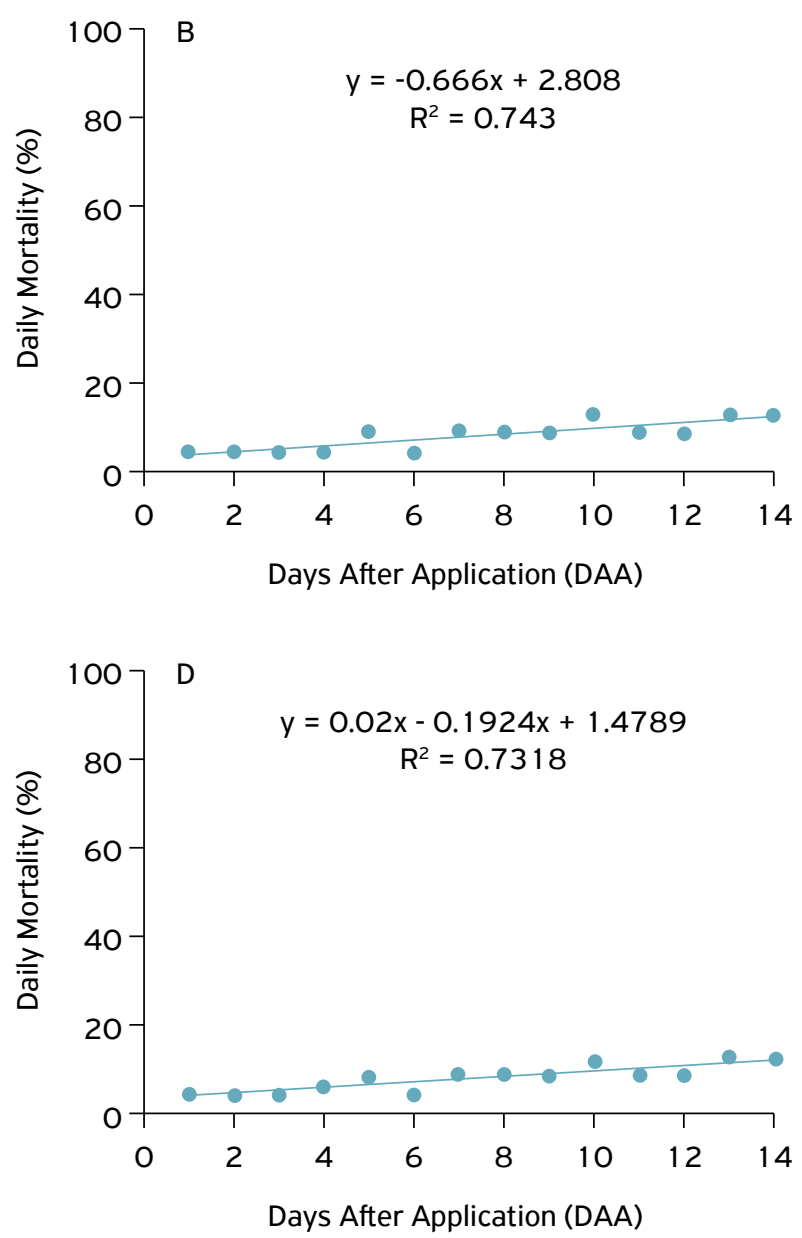

Figure 3. (A) Daily mortality of N. viridula; (B) N. viridula "Control treatment"; (C) D. melacanthus after application of the M. anisopliae (O8RA isolate) in greenhouse; (D) Dichelops melacanthus (Control treatment). 
Among the isolates of $M$. anisoplia researched, the 08RA isolate showed the greatest pathogenicity on the bug species in a shorter period of time compared to the isolates 05RA, 11RA and 02RA. According to several studies on the selection of $M$. anisopliae isolates, the greater pathogenicity of the species may be associated with the high genetic variability among the species. This genetic variation may provide the isolate with different conidial dimensions, growth rate and enzymatic activity when the spores come into contact with or penetrate the host body, which may promote host mortality and contamination (BRUCK, 2005). This fact that could have occurred with the 08RA isolate. The high pathogenicity of $M$. anisopliae on $N$. viridula and D. melacanthus pathogen species is associated with its rapid laboratory multiplication (LEITE et al., 2003; MASCARIN; QUINTELA, 2013). The use of $M$. anisopliae may be a promising alternative for the management of these insects in wheat crop. In addition to causing a reduction in the application of chemical insecticides, the use of $M$. anisopliae in the management of pests can cause horizontal dissemination of conidia in the soil for long periods, thereby increasing the concentration of the pathogen in the environment and promoting a more pronounced control of the pest in the course of time, especially in the off-season, when insects are sheltered in the soil or straw (ALMEIDA et al., 2007; BARBOSA et al., 2011). In laboratory and greenhouse conditions, the results obtained in this research provide support for the microbial control of $N$. viridula and D. melacanthus, and can reach satisfactory rates of population reduction of this pest. However, field studies are required in order to maximize control effectiveness.

\section{CONCLUSIONS}

Isolates of the fungi $M$. anisopliae are promising alternatives for the control of adults of $N$. viridula and D. melacanthus in the wheat crop, especially the 08RA isolate, which showed the highest pathogenicity in laboratory and greenhouse conditions.

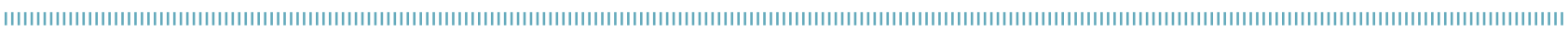
REFERENCES

ALMEIDA, J.E.M.; BATISTA FILHO, A.; DA COSTA, E.A.D. Efeito de adjuvantes em associação com Thiamethoxam 250 WG e Metarhizium anisopliae (Metsch.) Sorokin no controle de cigarrinha-da-raiz da cana-de-açúcar Mahanarva fimbriolata (Stal, 1854) (Hemiptera: Cercopidae). Arquivos do Instituto Biológico, São Paulo, v.74, n.2, p.135-140, 2007.

ALVES, S.B.; ALMEIDA, J.E.M. de; MOINO JR., A.; ALVES, L.F.A. Técnicas de laboratório. In: ALVES, S.B. Controle microbiano de insetos. Piracicaba:FEALQ, 1998. p.637-711.

AW, K.M.S.; HUE, S.M. Mode of Infection of Metarhizium spp. Fungus and Their Potential as Biological Control Agents. Journal of Fungi, London, v.3, n.30, 2017.

BARBOSA, R.H.; KASSAB, S.O.; FONSECA, P.R.B.; ROSSONI, C.; SILVA, A.S. Associação de Metarhizium anisopliae e thiamethoxam para o controle da cigarrinha-das-raízes em cana-de-açúcar. Ensaios e Ciência, São Paulo, v. 15, n.5, p.41-51, 2011.

BRUCK, D.J. Ecology of Metarhizium anisopliae in soilless potting media and the rhizosphere: implications for pest management. Biological Control, London, v.32, p. 155-163, 2005.

CARVALHO, L.W.T.; BROGLIO-MICHELETTI, S.M.F.; CARVALHO, L.H.T.; DIAS, N.S.; GIRÓN-PÉREZ, K. Incidência de Mahanarva fimbriolata después de aplicaciones de Metarhizium anisopliaee imidacloprid em caña-de-azúcar. Revista Caatinga, Pernambuco, v.24, p.20-26, 2011.

CHOCOROSQUI, V.R.; PANIZZI, A.R. Impact of cultivation systems onDichelops melacanthus (Dallas) (Heteroptera: Pentatomidae) populations and damage and its chemical control on wheat. Neotropical Entomology, Piracicaba, v.33, n.4, p.487-492, 2004.

EMPRESA BRASILEIRA DE PESQUISA AGROPECUÁRIA (EMBRAPA). Informações Técnicas para Trigo eTriticale - Safra 2012. Sistemas de Produção9. Dourados: Embrapa Trigo, 2011. 225p. Available from: <http://www.cnpt.embrapa.br/culturas/ trigo/informacoes_tecnicas_trigo_triticale_safra_2012.pdf >. Access on: 20 jun. 2015.

GOMEZ, S.A.; ÁVILA, C.J. Ameaça verde. Cultivar Grandes Culturas, Pelotas, v.5, n.61, p.28-29, 2004.

HENDERSON, C.F.; TILTON, E.W. Tests with acaricides against the brown wheat mite. Journal of Economic Entomology, v.48, p.157-161, 1955.

LEITE, L.G.; BATISTA FILHO, A.; ALMEIDA, J.E.M.; ALVES, S.B. Processos de produção.In: LEITE, L.G.; BATISTA FILHO, A.; ALMEIDA, J.E.M.; ALVES,S.B. Produção de fungos entomopatogênicos. Piracicaba: ESALQ, 2003. 92p.p.33-44.

LOUREIRO, E.S.; BATISTA FILHO, A.; MENDES, J.M.; PESSOA, L.G.A. Eficiência de isolados de Metarhizium anisopliae (metsch.) no controle da cigarrinha-da-raiz da cana-de-açúcar, Mahanarva fimbriolata (Stal, 1854) (Hemiptera: Cercopidae) em condições de campo. Arquivo do Instituto Biológico, São Paulo, v.79, n.1, p.47-53, 2012.

MANFREDI-COIMBRA, S.; SILVA, J.J.; CHOCOROSQUI, V.R.; PANIZZI, A.R. Danos do percevejo barriga-verde Dichelops melacanthus (Dallas) (Heteroptera: Pentatomidae) em trigo. Ciência Rural, Santa Maria, v.35, n.6, p.1243-1247, 2005. 
MARTINS, J.F.S.; BOTTON, M.; CARBONARI, J.J.; QUINTELA, E.D. Eficiência deMetarhizium anisopliaeno controle do percevejo-do-colmoTibraca limbativentris(Heteroptera:Pentato midae) em lavoura de arroz irrigado.Ciência Rural, Santa Maria, v.34, n.6, p.1681-1688, 2004.

MASCARIN, G.M.; QUINTELA, E.D. Técnica de Produção do Fungo Entomopatogênico Metarhizium anisopliae para uso em controle biológico. Goiás: Embrapa Arroz e Feijão, 2013. 18p. (Série documentos, 289).

MENT, D.; GINDIN, G.; ROT, A.; SOROKER, V.; GLAZER, I.; BAREL, S.; SAMISH, M. Novel technique for quantifying adhesion of Metarhizium anisopliae conidia to the tick cuticle. Applied and Environmental Microbiology, Lanham, v.76, p.3521-3528, 2010.

PANIZZI, A.R. O problema crescente de percevejos pentatomídeos em trigo no Sul do Brasil. In: CONGRESSO BRASILEIRO DE ENTOMOLOGIA, 25., Goiânia. Resumos. 2014. p.1.

PITT, J.I.;HOCKING, A.D. Food and Fungi Spoilage.2a ed. London: Blackie Academic \& Professional, 1997.593p.

RAMPELOTTI, F.T.; FERREIRA, A.; PRANDO, H.F.; GRUTZMACHER, A.D.; MARTINS, J.F.; TCANCENCO, F.S.; MATTOS, M.L.T. Patogenicidade de Metarhizium anisopliae (Metsch.) Sorokin sobre as fases do desenvolvimento de Tibraca limbativentris Stal (Hemiptera: Pentatomidae) em condições de laboratório. Arquivo Instituto Biológico, São Paulo, v.74, n.2, p.141-148, 2007.

ROHDE, C.; ALVES, L.F.A.; NEVES, P.M.O.J.; ALVES, S.B.; SILVA, E.R.L.; ALMEIDA, J.E.M. Selection of Beauveria bassiana (Bals.) Vuill. and Metarhizium anisopliae (Metsch.) Sorok. isolates against Alphitobius diaperinus (Panzer) (Coleoptera: Tenebrionidae). Neotropical Entomology, Piracicaba, v.35, n.2, p.23 1-240, 2006.
SAS INSTITUTE. Statistical Analysis System: getting started with the SAS learning. Cary, 2011.

SILVA, C.C.; LAUMANN, R.A.; BLASSIOLI, M.C.; PAREJA, M.; BORGES, $M$. Euschistus heros mass rearing technique for the multiplication of Telenomus podisi. Pesquisa Agropecuária Brasileira, Brasília, v.43, p.575-580, 2008.

SOSA-GÓMEZ, D.R.; MOSCARDI, F. Laboratory and field studies on the infection of stink bugs, Nezara viridula, Piezodorus guildinii, and Euschistus heros (Hemiptera: Pentatomidae) with Metarhizium anisopliae and Beauveria bassiana in Brazil. Journal of Invertebrate Pathology, Lanham, v.71, p.115-120, 1998.

SOSA-GÓMEZ, D.R.; SILVA, J.J. da. Neotropical brown stink bug (Euschistus heros) resistance to methamidophos in Paraná, Brazil. Pesquisa Agropecuária Brasileira, Brasília, v.45, n.7, p.767-769, 2010.

TIBOLA, C.S.; LORINI, I.; MIRANDA, M.Z. Boas práticas e sistema APPCC na pós-colheita de trigo. Passo Fundo: Embrapa Trigo, 2009. 20p. (Documentos Online, 105). Available from: <http://www.cnpt. embrapa.br/biblio/do/p_do 105.htm>. Access on: 2015 Dec 10.

XAVIER, L.M.S.; ÁVILA, C.J. Patogenicidade de isolados de Metarhizium anisopliae (Metsch.) Sorokin e de Beauveria bassiana (Bals.) Vuillemin a Scaptocoris carvalhoi Becker (Hemiptera: Cydnidae). Revista Brasileira de Entomologia, Curitiba, v.50, n.4, p.540-546, 2006.

WAQUIL, J.M.; OLIVEIRA, L.J. Percevejo barriga-verde: nova prioridade das culturas em sucessão à soja. EMBRAPA Milho $e$ Sorgo, Sete Lagoas, 2009.3p. Available from: <https://www. infoteca.cnptia.embrapa.br/infoteca/bitstream/doc/580457/1/ Percevejobarriga.pdf > . Access on: 2015 Dec 22. 